\title{
Placing the Grandy Sisters as Teachers in Pre-Confederation Newfoundland
}

\author{
Kay Whitehead and Judith Peppard
}

This paper draws on archival sources and interviews to explore the lives and work of four young women teachers, the Grandy sisters, in Newfoundland in the interwar years. We show that, notwithstanding the Department of Education's intentions to professionalize the occupation, three of the sisters were transients in the profession, teaching for brief periods as ungraded and third-grade teachers in outport communities, while Winnie, the fourth sister, was ultimately accorded professional status on the basis of her qualifications, experience, and eleven-year career. The paper also explores the geographic and social meanings attached to the places in which these young women taught, and we argue that factors such as race, gender, and religion shaped their identities and experiences in Newfoundland schools.

Ce texte s'appuie sur des documents d'archives et des entrevues afin d'explorer la vie et le travail de quatre jeunes institutrices de Terre-Neuve, les sœurs Grandy, pendant la période de l'entre-deux-guerres. Nous montrons que, malgré l'intention du ministère de l'Éducation de professionnaliser le métier, trois des sœurs firent un passage éphémère dans l'enseignement, n’excerçant que durant de courtes périodes en maternelle et en troisième année dans des villages de pêcheurs isolés. La quatrième sœur, Winnie, obtint finalement un statut professionnel en raison de ses compétences, de son expérience et d'une carrière de onze ans dans l'enseignement. L'article explore également les significations géographiques et sociales liées aux endroits où ces jeunes femmes enseignèrent. Nous soutenons que des facteurs tels que l'ethnie, le genre et la religion façonnèrent leur identité et leur expérience dans les écoles de Terre-Neuve.

In 1920 the Newfoundland government passed a new Education Act, one feature of which was the establishment of a Department of Education to oversee the workings of all state schools. This new administrative apparatus inherited an underfunded collection of one thousand and fiftythree mostly one-room schools that belonged to the Church of England, Roman Catholic, and Methodist Churches. Schooling was neither free nor compulsory so the Department had no jurisdiction over students, most of 
whom had left school by the age of twelve. ${ }^{1}$ However, it was empowered to advise on curriculum and, of particular import to this paper, deal with the training and certification of teachers. ${ }^{2}$ The Education Act provided for four grades of certificated teachers, the minimum qualification being a third-grade teacher. Below that, however, was a category of "ungraded teachers who were unqualified and employed on a temporary basis. A Normal School was established in St John's in 1921 but its fees were far beyond the means of most potential teachers' families. Another avenue for improving teachers' qualifications was offered by W.W. Blackall, who, in his capacity as Superintendent of Church of England schools, wrote to all Church of England teachers offering correspondence lessons to enable them to qualify for the next grade. ${ }^{3}$ However, in his report to the Department of Education in 1923, the Superintendent lamented about the state of the teaching profession:

I regret to say that we still have too large a proportion of teachers in the lower grades...the female teachers are the principal offenders....and it is for them to shew more ambition to fit themselves for their great responsibility to the children of this country. ${ }^{4}$

This comment suggests that neither the introduction of the Normal School nor the proffered correspondence lessons produced the desired results. In 1923 one-quarter of the teachers in Church of England schools were ungraded and a further forty per cent held the third-grade certificate. The few teachers with second-grade or higher certificates were the only ones conceptualized as professionals by the Department of Education. A similar profile of teachers existed in the other denominations' schools and the composition of the Newfoundland teaching workforce did not change dramatically in the interwar years. ${ }^{5}$

Within this context, our paper focuses on the social, professional, and geographic situations or places of four sisters - Amy, Bett, Sue, and Winnie Grandy - who taught in Church of England schools as both ungraded and graded teachers in the 1920s and 1930s. First, we describe the Grandys' social and economic position in Garnish, where the sisters spent their childhood years, and we argue that the family's active involvement in the Church of England and commitment to respectability

1 "Report of the Deputy Minister of Education,” Annual Report of the Department of Education, Newfoundland, 1919/20, v; P. McCann, "Class, Gender, and Religion in Newfoundland Education, 1836-1901," Historical Studies in Education/Revue d'histoire de l'éducation 1, 2 (1989): 183.

2 F. Rowe, The Development of Education in Newfoundland (Toronto: Ryerson Press, 1964), 71, 126-29.

3 Superintendent W.W. Blackall, Report of the Public Schools of Newfoundland under the Church of England Board for the Year ended 30 June 1919, xxxii-xxxv.

4 Ibid.

5 Ibid. 
meant that the sisters were well placed to enter the teaching workforce. The second section of the paper explores the brief periods of work of Amy, Bett, and Sue as teachers in the 1920s. Here, the focus is on explicating their social positions as ungraded and, in the case of Sue, third-grade teachers in outport communities, both from the Department of Education and the Grandy family's perspectives. By way of contrast, we trace Winnie Grandy's career from ungraded to second-grade teacher in the 1930s and early 1940s in the following sections of the paper. We argue that Winnie's initial placement as an ungraded teacher was more socially and geographically problematic than those of her sisters, but her subsequent career path aligned with the Department and her family's profiles of an ambitious and successful member of the profession.

In focusing on women teachers this paper will contribute to the existing research on the teaching profession in Newfoundland in the preconfederation era. Phillip McCann has shown that the profession was feminized in the twentieth century, as was the case in neighbouring Canada, and that women teachers were poorly paid compared with their male colleagues, and more likely to be unqualified and to be teaching in outport communities. ${ }^{6}$ Aside from McCann's overarching profile of the teaching workforce, occasional glimpses of women teachers' careers in the interwar era appear in reminiscences of Newfoundland students. ${ }^{7}$ Women teachers’ perspectives are registered in Christina Bradley's and Grace Layman's autobiographies, while Alice Collins' and Patricia Langlois' oral history research elucidates teachers' lives and work from the 1930s to the present. ${ }^{8}$ In focusing on four teaching sisters this paper offers further insights into the place of ungraded as well as certificated teachers in the Newfoundland school system.

$6 \quad$ P. McCann, Schooling in a Fishing Society: Education and Economic Conditions in Newfoundland and Labrador, 1836-1986 (St. John's: Memorial University of Newfoundland, Institute of Social and Economic Research, 1994). For the Canadian situation see J.D. Wilson and P. Stortz, “"May the Lord have Mercy on You': The Rural School Problem in British Columbia in the 1920s," in Children, Teachers and Schools in the History of British Columbia, ed. J. Barman, N. Sutherland, and J.D. Wilson (Calgary: Detselig Enterprises, 1995), 209-33; D. Hallman, “'A Thing of the Past”: Teaching in One-room Schools in Rural Nova Scotia, 1936-1941," Historical Studies in Education/Revue d'histoire de l'éducation 4, 1 (1992): 114; H. Harper, "White Women Teaching in the North: Problematic Identity on the Shores of Hudson Bay," in Dismantling White Privilege: Pedagogy, Politics and Whiteness, ed. N. Rodriguez and L. Villaverde (New York: Peter Lang, 2000), 127-43.

7 D. Mulcahy, "A Formal and Informal Education in Fair Haven, Placentia Bay, 1911-1958," Newfoundland Studies 11, 2 (1995): 283-307; A. Tizzard, On Sloping Ground (St John's: Breakwater Books, 1984), 60-65.

8 C. Bradley, "An Outport Teacher Remembers," in Blackboards and Briefcases: Personal Stories by Newfoundland Teachers, Educators and Administrators, ed. P. McCann (St John's: Jesperson Press, 1982); G. Layman, That Part of My Life (St John's: Harry Cuff Publications, 1994); A. Collins and P. Langlois, "I Knew I Would Have to Make a Choice': Voices of Women Teachers from Newfoundland and Labrador," Newfoundland Studies 11, 2 (1995): 308-28. 
Our paper draws on an array of sources. Conventional sources such as the Department of Education and Superintendent of Church of England Schools' annual reports reveal how the legislative, religious, fiscal, and geographic context shaped the work of young women who taught in Newfoundland and Labrador in the pre-Confederation era. However, there is a dearth of educational records for the period that coincides with Commission of Government (1934-1949). Much of the information collected by supervisors of schools, for example, was not published and aside from some teachers' records, there is little documentary evidence about individual teachers. The archival record contains information about three of the four Grandy sisters' appointments, salaries, certification, and, in the case of Winnie, attendance at summer school. In addition to the archival records we have drawn on two interviews conducted with Winnie Grandy in the 1990s in which she reflected on her early teaching experiences; a photograph album compiled by Winnie during her teaching years; and recent interviews with Grandy family members.

The two interviews with Winnie provide insights into how she interpreted her early teaching life. Kathleen Weiler argues that such sources provide "evidence of the ways in which human beings make sense of and evaluate material practices and conditions through the discourses available to them." "Winnie's photo album records her social life during her time as a second-grade teacher. A critical engagement with Winnie's photo album suggests that she selected and arranged these visual images in order to represent herself as belonging in the communities in which she taught. ${ }^{10}$ None of the teaching sisters are alive today but interviews conducted recently with two of their siblings, now in their mid-eighties, and twelve of their children provide insights into the ways in which their sisters' and mothers' brief periods of paid employment prior to marriage operate as "enabling fictions" within the family, that is, they construct a coherent and positive picture of these women's work as teachers. ${ }^{11}$ In "Oral History in Education," Phil Gardner points out that the "force of the spoken word for historical analysis always rests upon its intimacy, together with its rootedness in the local, the personal, and the particular" and it was the local, the personal and the particular that these interviews

9 K. Weiler, Country Schoolwomen: Teaching in Rural California, 1850-1950 (Stanford: Stanford University Press, 1998), 6.

10 For further discussion on the critical use of photography see I. Grosvenor, "On Visualising Past Classrooms," in Silences and Images: The Social History of the Classroom, ed. I. Grosvenor, M. Lawn, and K. Rousmaniere (New York: Peter Lang, 1999), 83-104; K. Rousmaniere, "Questioning the Visual in the History of Education," History of Education 30, 2 (2001): 109-16.

11 The interviews were conducted in June 2003 by Judith Peppard, Winnie Grandy’s daughter, and were funded by a Flinders University Small Grant entitled "Transients in the Teaching Profession in the Interwar Years"; for a discussion of enabling fictions see B. Pamphilon, "Telling Tales Out of School: The Weaving of School Stories into Life Stories," History of Education Review 32, 1 (2003): 35. 
were able to elucidate. ${ }^{12}$ The interviews also invoke discourses of teaching in circulation in Newfoundland from the 1920s to the 1940s.

By using a variety of sources this paper brushes the official published record against the oral and pictorial accounts of members of the Grandy family. ${ }^{13}$ It opens "a channel through which documentary sources and oral testimony speak to each other in what Paul Thompson and Michael Roper have called a reconstructive mode."14 Drawing on all of these texts, then, this paper discusses the material conditions under which the Grandy sisters lived and worked in Church of England schools during the period from 1920 to 1944.

\section{"It was either teaching or nursing"}

Amy, Sue, Bett, and Winnie Grandy and their five sisters were born in Garnish, a coastal town on the Fortune Bay side of the Burin Peninsula. Their parents were George and Jessie Grandy. According to the 1921 census Garnish boasted a population of over seven hundred people. ${ }^{15}$ Fishing was the main source of employment for male bread-winners and George Grandy was no exception. His daughter Jessie described her father's life this way: "[He was] ten years old when he went fishing...and then after that he got the boat, the schooner they were called...he was out from another firm that owned the schooner and he was skipper on her, all his life really, until he retired." ${ }^{\prime 6}$ George spent much of the year at sea and when he was home - typically from December to March - he helped out at the church, doing painting and carpentry work. His wife Jessie was also active in church life and was president of the Anglican Church Women's Association (CWA) for a time. ${ }^{17}$ The Grandy family's involvement with the church and George's work as captain of a fishing vessel conferred social status in a place like Garnish where the majority of the population was affiliated with the Church of England and involved in the fishing industry.

Within the Grandy family education was deemed important. George Grandy's mother, Sabine, had been the postmistress in Garnish, a position that required a level of education, and family accounts suggest that Jessie

12 P. Gardner, “Oral History in Education: Teachers' Memory and Teachers' History,” History of Education 32, 2 (2003): 187.

13 For a discussion of the notion of "brushing history against the grain," see Walter Benjamin, "Theses on the Philosophy of History," in Illuminations, ed. H. Arendt, translated by H. Zohn (London: Jonathan Cape Ltd, 1970), 259; see also Joyce Goodman's discussion of the use of montage in J. Goodman, "Troubling Histories and Theories: Gender and the History of Education,” History of Education 32, 2 (2003): 159.

14 Cited in Gardner, "Oral History in Education,” 184.

15 Provincial Archives of Newfoundland (hereafter PANL), 1921 Census of Newfoundland, Garnish, Microfilm Reel M-8036, 1-22.

16 J. Kittilsen, transcript of an interview with Judith Peppard, June 2003.

17 Ibid; M. Potempa, transcript of an interview with Judith Peppard, May 2003. 


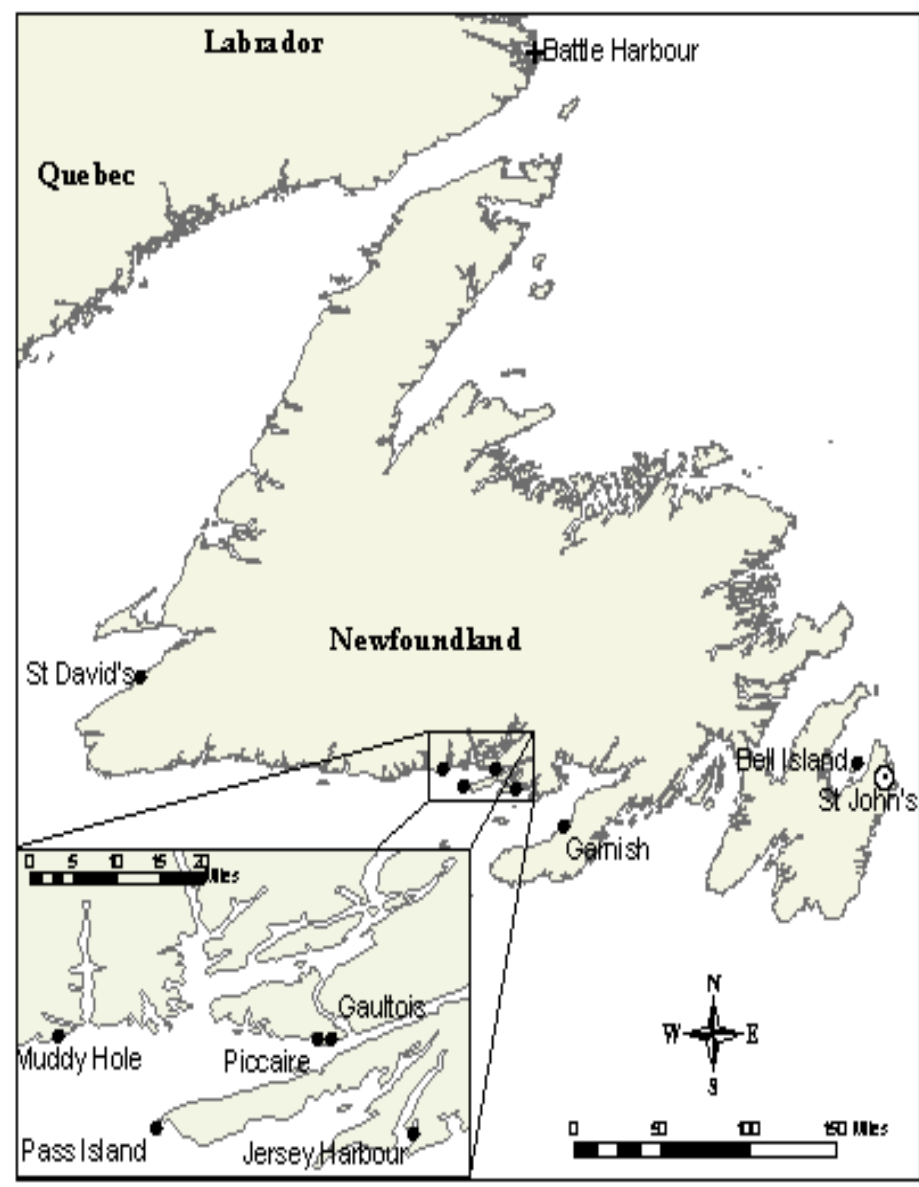

Map created by Jacqueline Best, Spatial Information Laboratory, Flinders University 
Grandy encouraged her daughters to attend school. ${ }^{18}$ As a relatively large community Garnish would have been privileged within the populationbased funding model used by the Department of Education and thus likely to attract the services of an experienced teacher for the full year. ${ }^{19}$ This also meant that students were more likely to have access to a teacher who could prepare them for the annual Council of Higher Education (CHE) examinations. However, few students undertook these exams, for a number of reasons. First of all, children were often involved in the cottage economy and thus attended school irregularly. Second, in order to sit the exams students had to register their intent in advance and pay a fee for the privilege, and the fee would have been beyond the means of many families. Third, the possibility of failure was high as only about half of the students who sat the CHE exams passed. ${ }^{20}$

In 1922 the Church of England school board in Garnish addressed the last problem by employing Jacob Morgan as the teacher and giving him the task of bringing the school from elementary to high school level. It seems he achieved this in two years and was known for his students' success in the CHE exams. ${ }^{21}$ Grandy family accounts suggest that the social connection established between the Morgan and the Grandy families (the Morgans boarded with the Grandys when they first arrived in Garnish and maintained contact thereafter), combined with Jessie Grandy's commitment to her daughters' education, strengthened the importance of education and school attendance in their minds. ${ }^{22}$ At least some of the Grandy sisters benefited from Jacob Morgan's teaching and, indeed, they were relatively well-educated compared with the majority of the population in Newfoundland.

The Grandys' commitment to religion, education, and community service, along with George's steady employment, are indicative of the family's social position and values. According to Winnie, the Grandys were "a respectable family" and she and her sisters portrayed Garnish as a "law-abiding place."23 Kathleen Weiler suggests that respectable women "often spoke and represented themselves as what we would call middle class, as conservers and defenders of the moral order," and this is certainly the case with the Grandy sisters. ${ }^{24}$ Given these understandings, the local store-owner's affair with his assistant and her subsequent pregnancy was seen to be "a big disgrace" and a blot on the otherwise law

Ibid.

R. Andrews, Integration and Other Developments in Newfoundland Education,

1915-1949 (St John’s: Harry Cuff Publications Ltd., 1985), 19.

20 Ibid., 92, 98.

21 Cyril F. Poole, Mose Morgan: A Life in Action (St. John’s: Harry Cuff Publications Ltd, 1998), 24-25.

22 Ibid., J. Kittilsen, transcript of an interview with Judith Peppard, June 2003.

23 W. Grandy, transcript of an interview with Judith Peppard, Jan. 1991.

24 Weiler, Country Schoolwomen, 124. 
abiding community of Garnish. ${ }^{25}$ Although the Grandys did not necessarily have access to substantial economic resources, their adherence to a respectable lifestyle would provide sufficient social capital for the daughters to be considered suitable applicants for teaching positions.

By the 1920s many young women were being expected to earn a living prior to marriage but there were few options for respectable paid work in Garnish. When asked about the work available for young women, Jessie, the second youngest of the Grandy sisters, responded without hesitation,

not very much. That's why we had to leave...There wasn't much to do there at all. The work in the store or work in the bank, but the bank was too far away and in them days, everybody didn't have cars you know...so they work in little stores around there and most of them stayed home and they helped the parents, but then y'see the schooners would go out fishing and bring their fish in. They'd salt their fish at sea, bring it in and wash it and they'd have to dry it on the flakes, you know, on the beaches. Well, women had to do that. $^{26}$

Meta Potempa, the youngest of the Grandy sisters, recalled that "they just grew up and got, like my two older sisters were married at eighteen. They just got married." And "it was either teaching or nursing...or domestic., ${ }^{27}$ In relation to the latter, Sue Grandy's daughter, Joyce Campbell, pointed out that while domestic work would have been an option for young women, it was not a very desirable one. She indicated that going "in service" meant being responsible for "housekeeping and child care and maid of all work in rich people's homes. The division of wealth and poverty in Newfoundland was extreme. The wealth of course was concentrated in St. John's." ${ }^{28}$ Nancy Forestell's thesis on women's paid labour in St John's between the wars supports this view. She found that domestic work was often accompanied by a range of problems for young women from the outports, among them poor pay or not being paid at all, demanding work, and long hours. ${ }^{29}$ So if a young woman from a respectable family had done reasonably well at school and wanted paid employment that was more stimulating than domestic work with greater

\footnotetext{
25 W. Grandy, transcript of an interview with Judith Peppard, Jan. 1991.

J. Kittilsen, transcript of an interview with Judith Peppard, June, 2003.

M. Potempa, transcript of an interview with Judith Peppard, May 2003.

J. Campbell, transcript of an interview with Judith Peppard, June, 2003.

N. Forestell, "Women's Paid Labour in St John's Between the Two World Wars" (M.A. thesis, Memorial University of Newfoundland, 1994); see also L. Cullum and M. Baird, "A Woman's Lot: Women and the Law in Newfoundland from Early Settlement to the Twentieth Century," in Pursuing Equality: Historical Perspectives on Women in Newfoundland and Labrador, ed. L. Kealey (St. John's: Memorial University of Newfoundland, Institute of Social and Economic Research, 1993), 97.
} 
status, "it was either teaching or nursing," and as Meta Potempa indicated, "my sisters seemed to go in for teaching." 30 The school in Garnish, however, was relatively large and well established, and thus more likely to attract experienced teachers. Therefore each of the Grandy sisters who wanted to teach would need to leave home to achieve her ambition.

Amy, the second oldest of the nine daughters, was the first to go in for teaching. It is likely that she was seventeen years old when she applied for a place in Newfoundland schools, and thus met the first of the Department of Education's requirements, that prospective teachers had to be at least seventeen years old. Next, applicants for teaching positions were required to

satisfy the Board of Examiners that they are free from serious bodily defect, are of good constitution, enjoy good health, bear a good moral character and are duly qualified to give instruction to classes in physical exercises according to some well recognized system. ${ }^{31}$

Given the emphasis on respectability in the Grandy family, Amy was well placed to meet the test of moral character. Applicants needed to furnish the Church of England Board of Examiners with character references from their local minister and presumably she had no difficulties in procuring such documentation. However, her qualifications were a different matter. Amy was well educated by the standards of the day in Newfoundland but it is unlikely that she had taken the CHE's preliminary examination, which would have enabled her to qualify as a third-grade teacher. As previously mentioned, however, the Education Act provided for the employment of ungraded teachers on short-term contracts. ${ }^{32}$ No official records were kept for ungraded teachers as their "teaching service did not carry any credit for certification or pension purposes." 33 Thus the regulations and practices that governed their employment assumed that such teachers would be transients in the profession and it seems that their suitability was assessed in terms of their age and character. It is likely, therefore, that Amy's membership in a respectable family was of prime consideration in the Board's assessment of her application to teach in Church of England schools. She was placed in her first school as an ungraded teacher, as were Bett and Winnie in the years that followed.

In essence, Amy, Sue, Bett, and Winnie Grandy were brought up in a family whose values matched the minimum requirements to teach in Newfoundland schools. Their active membership in the Church of

Potempa, transcript of interview with Judith Peppard, May 2003.

Newfoundland, Education Act 1927, 24.

Ibid.

PANL, Letter from M. Burke to W. Brown, 11 June 1979, inserted in Anglican Transfers Service/Payroll Records Book One A-K, 1907-48, PRC \#21, Box \#5, file AE3. 
England would also stand them in good stead in communities that were like their own in Garnish, whatever their tenure. The following section focuses on the work in the 1920s of the three sisters, Amy, Bett, and Sue, who were, indeed, transients in the profession.

\section{"These teachers have to take their...places in a very isolated part of the island where they are leaders"}

Amy Grandy probably began teaching just after the Newfoundland government passed the Education Act of 1920. The newly created Department of Education was struggling to come to terms with the state of the teaching workforce, which had lost many male teachers during World War One, making it more reliant on the labour of third-grade and ungraded women teachers. Of the 425 teachers employed by Church of England School Boards, over 60 per cent were women. Of those, 50 per cent held the third-grade certificate and a little over 30 per cent were ungraded. Even with their participation, forty Church of England schools had remained closed in the 1919-20 school year because of teacher shortages and "many children lost a year's education." 34 A further thirty schools had operated for three-quarters of the year, forty-nine for half a year, and forty-five for a quarter of the year. While this was a by-product of the population-based funding formula used by the Department of Education, partially offset by grants for Sparsely Populated Localities, with the school open only five months a year there was no continuity in children's education even if they could attend regularly. ${ }^{35}$ Given this situation and the teacher shortage, it could be that Amy Grandy had little difficulty finding a place to teach.

Amy's tenure as a teacher in the Church of England school in Piccaire is recorded in the Department of Education's 1921/22 Annual Report but Amy's children recall that their mother's first teaching appointment was at Muddy Hole "when she was in her teens, sixteen or seventeen, something like that." ${ }^{36}$ Mary Bertha Morris, who was a student at Muddy Hole in the early 1920s, also remembers Amy Grandy teaching there. ${ }^{37}$ Both Piccaire and Muddy Hole are on the south coast of Newfoundland in the Hermitage Bay area and representative of the kinds of places that a young ungraded teacher might be sent to begin her career. The 1921 census indicates that Piccaire and Muddy Hole had populations

\footnotetext{
34 Superintendent of Church of England Board Schools report, Annual Report of the Department of Education, 1919/20, 4-5.

35 Andrews, Integration, 19.

36 Superintendent of Church of England Board Schools report, Annual Report of the Department of Education, 1921/22, 80-81; G. Piccott, transcript of an interview with Judith Peppard, June 2003.

37 M.B. Morris, transcript of an interview with Judith Peppard, June 2003.
} 
of around seventy and eighty respectively. ${ }^{38}$ A photo of Muddy Hole taken in 1912 shows a one-room schoolhouse tucked in behind the church on the side of a steep hill, a pictorial representation of the connection between school and church in Newfoundland, juxtaposed against the stark landscape that shaped the experiences of the people who worked and lived in outport communities. ${ }^{39}$

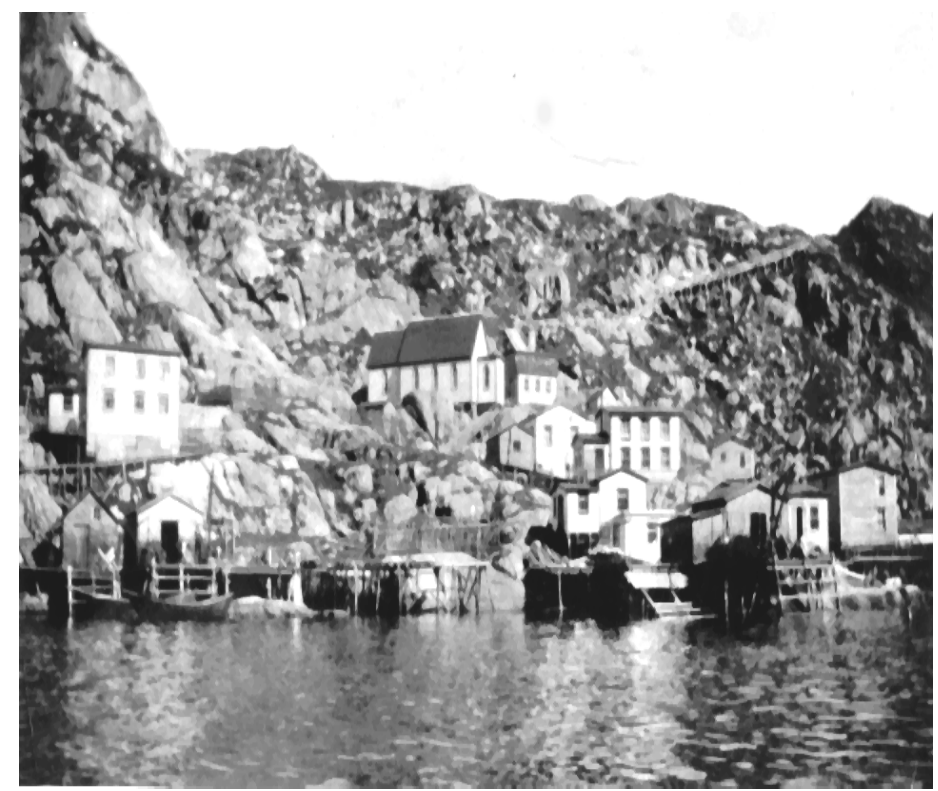

It may be that Amy taught at Muddy Hole during the first half of the 1921/22 school year and moved to Piccaire for the second half. This would fit with the Department's contractual arrangements for ungraded teachers; that is, they were granted a licence to teach for six months which could be renewed for another six months if their performance was satisfactory. Given the size of both places, it is unlikely that in a time of teacher shortage they would have been able to acquire the services of a teacher for a full year. Thus while we know from the official record that Amy Grandy taught in Piccaire during the 1921/22 school year, the stories in circulation in the Grandy family suggest that her first appointment was in Muddy Hole.

PANL, 1921 Census of Newfoundland, Piccaire, Muddy Hole, Microfilm Reel M8037.

39 Photo courtesy of Doug Wells, Harbour Breton, Newfoundland. 
The social conditions in which Amy Grandy worked and lived in Piccaire would have been quite different from those that prevailed in Garnish when she was growing up. With a population of over seven hundred Garnish was a large community by comparison. The geographic and social isolation potentially experienced by young women teachers was recorded by the Superintendent of Church of England schools in a description of his inspectorial visit to a school in an outport community in 1924/25. He suggested that the situation of the young woman teacher was neither an isolated case nor "the worst." She boarded with a large family in a "little cottage situated on a rock" and had little space to herself. With "no amusements" and only the weekly mail boat in summer to bring news from her family, he reported that the teacher was "extremely lonely" and felt "the dreariness and solitude of Sundays very much indeed." 40

However, the accounts of members of the Grandy family suggest that Amy did not feel isolated to the extent described by the superintendent. The family constructed Amy's identity around her religion and respectability, thereby enabling her to belong in Piccaire, which "was all Anglicans." Her sister Jessie emphasized Amy's connections to the Church of England and her importance in the community: "she used to have the church service there and teach Sunday School...The minister would only come once a month. The rest of the time Amy did everything there." ${ }^{41}$ Amy met her future husband, a fisherman, at Piccaire and soon resigned from teaching. Although there was no official marriage bar in the education regulations, most women did resign when they married.

If Amy's paid work as a teacher was brief, then Bett's tenure at Flat Island was even more so. We were unable to find any teaching record of her service with the Department of Education. The Grandy family suggests that she taught briefly, possibly in a place called Flat Island, but that she "didn't like teaching. The place was too small, very small so I don't know if she finished the year or not. But then she went to Glace Bay ....and worked in a store." ${ }^{42}$ Such transience among women teachers was not uncommon during this era, nor was migration to Canada in search of work.

Sue, the third of the teaching sisters, was granted her third-grade certificate on 1 January 1926 and taught for more than four years. In contrast with ungraded teachers, third-grade teachers' service was recognized by the Department of Education, they were able to join the teachers' pension fund from the age of twenty-one, and records were kept

40 Superintendent of Church of England Board Schools report, Annual Report of the Department of Education, 1924/25, 39.

41 J. Kittilsen, transcript of an interview with Judith Peppard, June 2003.

42 Ibid. See also J. Brown, transcript of an interview with Judith Peppard, June 2003. 
for each teacher. ${ }^{43}$ Such record-keeping generates a sense of permanency about the category of third-grade teacher even though individual teachers were likely to be transient. Sue had the good fortune to have been taught by Jacob Morgan in Garnish and it could be that this experience enabled her to avoid her sisters' fate, that is, beginning work as an ungraded teacher. Stories about Sue's teaching that circulate among the Grandys position her somewhat differently from Amy and Bett on the basis of her education, the size and location of the places in which she taught, and thus the size of the school.

The places in which Sue found teaching positions were more substantial than those of her sisters. She spent a year in each of three schools, Jersey Harbour, Gaultois, and Pass Island, in the Hermitage Bay area, which was "all Church of England," unlike nearby Bay D'Espoir, where there were "a lot of Catholics and Indians." ${ }^{\text {" Jersey Harbour had }}$ a population of 210 people (forty-six households) in 1921, well over twice the size of Muddy Hole, where Amy first taught. ${ }^{45}$ Gaultois was on Long Island on the western shore of Hermitage Bay, about a mile from Piccaire. It was the larger of the two communities and people from Piccaire went there to shop for supplies. Members of the Grandy family spoke of Jersey Harbour and Gaultois as wealthy places where merchants were based. Pass Island was one of only thirty "Superior Elementary Schools" under the Church of England's jurisdiction. ${ }^{46}$ It was a two-room school and so was Long Pond, where Sue spent her final eighteen months teaching the lower grades. Long Pond was among the minority of places outside St John's where there was more than one school. In 1925/26, for example, there were 370 Church of England schools outside St John's. "Two hundred and forty-two were the only schools in the settlement, thirty-two had a Roman Catholic school nearby and ninety-six were in mixed communities." ${ }^{37}$ Sue's teaching was thus qualitatively different from Amy and Bett's in that she taught larger numbers of students and in Long Pond and Pass Island she worked with other teachers.

Although Sue moved schools frequently, she was portrayed as establishing close relationships with people in each community that lasted long after her brief tenure. She was said to be "very outgoing" with "a boyfriend in every community she taught in. She was very active with

43 See Sue's teaching record in PANL, Church of England Teachers Pension Accounts A-K, Department of Education, PRC \#21, R1, Box \#3.

44 G. Piccott, transcript of an interview with Judith Peppard, June 2003.

45 PANL, 1921 Census of Newfoundland, Jersey Harbour, Microfilm Reel M-8037, 190-196.

46 G. Piccott, transcript of an interview with Judith Peppard, June 2003; J. Richards, transcript of an interview with Judith Peppard, June 2003; Superintendent of Church of England Board Schools report, Annual Report of the Bureau of Education, 1926/27, 31. 47 PANL, R. Andrews, "A Brief Survey of the School System in Newfoundland Together with Some Suggestions for its Improvement,” 4, in Andrews, Ralph, Personal Files 1920s-1970s, MG 895, Box 6. 
church work so that she and the Minister's wife were usually quite good friends. ${ }^{\prime 8}$ Like Amy, Sue was seen as a respectable and important young woman because of her affiliation with the church and because the parents respected her teaching. However, she told her daughter, Joyce, that

she didn't really like teaching because at one point she had eighty something children...in her classroom and she said she especially disliked teaching home economics, sewing and knitting and needlework...So I think she was quite delighted when she got married. ${ }^{49}$

Sue met her future husband, the teacher of the upper classes at Long Pond, and soon became the teacher's wife. Sue's daughters recalled that their mother's connections with the Department of Education were not severed entirely, however, for visiting supervisors "always came to our house for the midday meal which my mother prepared for them." ${ }^{50} \mathrm{Her}$ community involvement also continued to be vigorous. She often attended meetings in the evenings and

was instrumental in raising money for the Women's Patriotic Association and organizing women to knit socks and putting on dinners, suppers we called them in Newfoundland, to raise money. She was very active in girl guides. She was district commissioner for the Girl Guides. ${ }^{51}$

The Grandy family understood Amy, Bett, and Sue as having teaching careers located in places that were Anglican and much like their own community in Garnish. Likewise, the annual reports portrayed individual communities in Newfoundland as relatively homogeneous:

Fortunately the people along this extensive coastline are generally settled in groups according to their religious affiliations, and thus while these three denominations constitute nearly ninety-four per cent of the population, yet of all the settlements outside of St John's in which the three larger denominations conduct schools, there are only nineteen in which all three denominations have a school. ${ }^{52}$

Given this situation, there was potential for young women teachers to find at least some people with similar social standing and religious

\footnotetext{
48 J. Campbell, transcript of an interview with Judith Peppard, June 2003.

49 Ibid.

50 Ibid., J. Walsh, transcript of an interview with Judith Peppard, June 2003; the supervisors included Ralph Andrews. Andrews, Integration, 216.

51 J. Campbell, transcript of an interview with Judith Peppard, June 2003.

52 Secretary of Education, Statistical Report of the Bureau of Education for the Fiscal Years ended June 30, 1931, 1932, 1933, 5.
} 
beliefs when they moved away from home. Certainly it was important to find board with respectable families. Playing an active role in the local church also facilitated a sense of belonging and, as members of the Grandy family pointed out, some influence in the community. There is some support for this perspective among school administrators such as Ralph Andrews, a supervisor in the 1930s, who commented:

The teachers have to take their places in a denominational system, some of them in a very isolated part of the island where they are leaders, in a far truer sense, than it is necessary for most teachers to be. ${ }^{53}$

Notwithstanding these young women teachers' importance to their communities and to the Department of Education, which would have ceased to function without their labour, most ungraded and third-grade teachers were transients in the workforce; they moved schools frequently and resigned within a few years. Amy and Bett did not stay long in each place and Sue also shifted school each year until she reached Long Pond. Aside from the comment that Bett left Flat Island partly because it was too small a place, interviews with Grandy family members did not reveal why Amy and Sue also moved schools, especially when they were seen to be integral members of their Anglican communities. The explanation of the Superintendent of Church of England schools for teachers' transience was that some moved "in search of promotion, but more often than not it is because the conditions of life cannot be endured for more than one school year." 54 From the Department's perspective, transience was an ongoing administrative and educational issue. When teachers changed schools, they often neglected to submit their returns, thereby disrupting the compilation of statistics and annual reports. And at the school level each new teacher had to begin afresh in establishing relationships with her students and took time to ascertain their progress. However, administrators empathized with the difficulties faced by young ungraded teachers and from the Superintendent's perspective, affiliation with the church did not mediate the conditions of life in many places to the extent that they would stay for more than one year.

A problem that was related to transience was the status of the profession in Newfoundland. Administrators claimed that not only were there too many transient teachers, but ungraded and third-grade teachers like Amy, Bett, and Sue also lacked the ambition to improve their qualifications, and by implication their professional status and efficiency

53 Andrews, “A Brief Survey of the School System,” 9.

54 Superintendent of Church of England Board Schools report, Annual Report of the Department of Education, 1924/25, 37; see also ibid., Annual Report of the Department of Education, 1922/23, 12-13; Secretary for Education's report, Annual Report of the Department of Education, Newfoundland, 1940, 19, and 1941, 19. 
and that of the school system. ${ }^{55}$ Here the department was caught in a cleft stick. It could not function without such women but it had neither the power nor the resources to demand that they upgrade. Conceptualizing the problem as a lack of ambition shifted responsibility onto the teachers but it did not resolve the issue. As far as the Grandy sisters' ambition was concerned, family members insisted that both Bett and Sue did not like teaching and were glad to leave the job, but perhaps this was not so much the case with Amy, who maintained her links with teaching after she married, substituting at her children's school when the teacher was absent. $^{56}$ Winnie, the last of the sisters to go in for teaching, was a different matter. Winnie was portrayed as ambitious and although she began her career as an ungraded teacher in a very difficult situation, she improved her qualifications, thereby enhancing her status and that of the profession in the eyes of the Department of Education. ${ }^{57}$

\section{“That's no place for her”}

By the time Winnie, the seventh child of the Grandy family, made the decision to teach in 1933 there had been some significant changes in the Department of Education's regulations and practices relating to teachers' career paths. The 1927 Education Act retained the category of ungraded teacher but implemented five levels of graded teachers. Summer school courses were introduced as another option for teachers to qualify for the third and second grades but attendance at the Normal School was a requirement for entry into the higher levels of the profession. Of particular import to teachers was a variation in government funding under the 1927 Act, the consequence being that salaries fluctuated in the following years and were slashed by 50 per cent in the economic depression of 1932-33. The Normal School was also closed in 1932, which was the year before Winnie applied for a position in Church of England schools. The institution of the Commission of Government in 1934 brought some stability and funding into Newfoundland's school system; teacher training was re-established at Memorial University College in 1934 but continued to be beyond the financial resources of most families, including the Grandys. Summer schools were reinstated but the Department only accepted limited numbers of applicants so providing an adequate supply of qualified teachers remained a major problem. Teachers' salaries were gradually increased but it was not until 1936 that they reached their 1931 levels. It continued to be the case that

55 Superintendent of Church of England Board Schools report, Annual Report of the Department of Education, Newfoundland,1921/22, 22, and 1922/23, 3.

56 M. Story, transcript of an interview with Judith Peppard, June 2003.

57 J. Peppard, transcript of reflections on Winnie Grandy, Feb. 2003; M. Mercieca, transcript of an interview with Judith Peppard, June 2003; J. Campbell, transcript of an interview with Judith Peppard, June 2003. 
women teachers received about 80 per cent of the men's wage for doing the same work. ${ }^{58}$ Such was the context in which Winnie would make the decision to teach and find a place in the school system.

Winnie had begun her schooling in Garnish but it was disrupted by her mother's death and father's remarriage. She continued to Grade X at Kelligrews while living with her sister Sue, who was by then married with small children. Like many young women of the time Winnie attended school irregularly and helped with domestic duties. As previously stated there were limited opportunities to train as a teacher at this time but Winnie portrayed her decision to become a teacher as "making the most of" her limited education, and fulfilling her need to escape her domestic situation, and her appointment as an ungraded teacher to Battle Harbour in Labrador in 1933 as "the only place I'm going to get because I don't have any training. ${ }^{\text {59 }}$ Winnie did not wish to continue in unpaid domestic service. Teaching for her was to be respectable paid work that ensured a measure of economic and social independence.

Winnie followed a substantial portion of Newfoundland's coastline when she left her home and family and travelled by steamship to Battle Harbour, where she was ultimately to spend two years. In this place, where there was a Grenfell Mission and three Church of England schools, the people were "burdened with poverty," and the local Board of Education was in the process of negotiating with the Diocesan Synod in St John's for a loan to build a new school. ${ }^{60}$ Winnie did not return to Garnish for the intervening summer vacation but chose to take a teaching position up at Seal Island where there was an Inuit community. Notwithstanding the fact that Battle Harbour was predominantly Anglican, Winnie and other members of the Grandy family did not draw upon her religious affiliation to discuss her life and work and they did not portray her as belonging in the community. The following account will show that her first two years of teaching in such remote and unfamiliar places challenged her identity as a respectable young woman teacher.

Little is known of Winnie's teaching in Battle Harbour other than that she taught at Trapp Cove for one of the two years. For at least some of this time, however, she boarded happily with a family who had four sons. Grandy family members spoke of the boarding house as a safe place in which the men protected her from unspecified dangers, and Winnie spent some of her leisure time with the "boys," travelling by komatec and

58 Rowe, The Development of Education, 70, 128-29, 135.

59 W. Grandy, transcript of an interview with Judith Peppard, c. 1996.

60 Diocesan Magazine, Nov. 1934, 340; Minutes of meetings held 15 Sept. 1934 and 5 March 1935, in Minutes of Meetings of the Synod Education Committee, 1874-1974, 100.66, Diocesan Synod Education Committee, Box 1, Courtesy of the Diocese of Eastern Newfoundland and Labrador Archive, St John's; Encyclopedia of Newfoundland and Labrador, First Edition, Vol. 1, Ed. in Chief Joseph R. Smallwood, Managing Ed. Robert D.W. Pitt (St. John’s: Newfoundland Book Publishers Ltd, 1981), 146. 
dog team in the extraordinarily harsh and cold environs. She said, "I was always with one of the boys but I always liked to drive." ${ }^{61}$

Seal Island, however, was a different matter for she lived alone in a cottage attached to the school and there was no sense of belonging in an Inuit community where the people were so different from her. ${ }^{2}$ Indeed, Seal Island was equated with race and race with Blackness. As a young woman living and working alone Winnie was beyond male protection, and a white stranger in this community. Her sister Meta said that Winnie "taught the Eskimos" and argued that "she did not have any friends there, you know, there to associate with. The mothers and that, they weren't..."63 Her two daughters agreed that Winnie was "totally embarrassed" when "the natives of Labrador, they would be Inuit I guess, started lining up outside her door" seeking advice because they perceived her to have special "mystical powers" on account of her being the seventh child in the family. ${ }^{64}$ Winnie also recalled that the young men who lived in Battle Harbour "used to torment me. They'd say you're going to be black when you go back, eating all that seal meat. You're going to be black." ${ }^{65}$ Here, a racist discourse is being deployed "wherein it was thought that colour 'rubs off' - that white people who associate too closely with people of colour will take on their colour." ${ }^{\prime 6}$ However, the dangers posed by Seal Island were not solely attributed to race. Both of Winnie's sisters alluded to potential threats to Winnie's respectability posed by some drunken fishermen who spent the summers in Labrador. Meta said that "Winnie kept a dog tied up at her front door to protect her from the men that used to fish down there. They would come off the boats and they'd find out there was a woman there I guess." However, the fishermen "never got past the dog." ${ }^{67}$ Jessie said that the law-abiding fishermen from Garnish visited with Winnie and then told her father "to get her out of it, to get her to come home. That's no place for her." ${ }^{68}$ Nevertheless, the physical and social dangers posed to Winnie's respectability did not materialize, though they extended into the final hours of her sojourn. According to Winnie, the "little boat" that brought her back from Seal Island was caught in a violent storm off Cape Bluff, during which she was reassured of her safety by the engineer, "one of the boys" from Battle Harbour. ${ }^{69}$

61 W. Grandy, transcript of an interview with Judith Peppard, c. 1996; M. Potempa, transcript of an interview with Judith Peppard, June 2003; J. Kittilsen, transcript of an interview with Judith Peppard, June 2003.

62 M. Mercieca, transcript of an interview with Judith Peppard, June 2003.

63 M. Potempa, transcript of an interview with Judith Peppard, June 2003.

64 M. Mercieca, transcript of an interview with Judith Peppard, June 2003.

65 W. Grandy, transcript of an interview with Judith Peppard, c. 1996.

66 R. Frankenburg, White Women, Race Matters: The Social Construction of Whiteness (London: Routledge, 1993), 40.

67 M. Potempa, transcript of an interview with Judith Peppard, June 2003.

68 J. Kittilsen, transcript of an interview with Judith Peppard, June 2003.

69 W. Grandy, transcript of an interview with Judith Peppard, c. 1996. 
Winnie's experiences of her first teaching appointment at Battle Harbour and the stories that are promulgated within the Grandy family stand in stark contrast to those pertaining to her sisters' situations as ungraded teachers, and they are also different from the department's perspectives. Winnie taught in a place that was far more geographically isolated from Garnish than her sisters, but of equal importance was the understanding that she was socially "out of place." ${ }^{\text {" }}$ The potentially dangerous fishermen and the presence of the Inuit at Seal Island seemed to bring issues of gender and race to the fore in discussions of Winnie's first two years of teaching and indeed, the Grandys' stories demonstrate that places are invested with both geographic and social meaning. David Gruenewald argues that "places are social constructions filled with ideologies, and the experience of places...shapes cultural identities." ${ }^{\prime 11}$ The Grandys were able to preserve the identities of Amy, Sue, and Bett as respectable young women teachers by focusing on their religious affiliations but in Winnie's case it was much more difficult because she was living in a place so socially different from her own. The tensions thus generated dominate understandings and override the fact that Battle Harbour was also a predominantly Anglican community. Likewise the Department's annual reports focused on the religious homogeneity of communities in Newfoundland and argued that ungraded teachers felt lonely and out of place because of their inferior living and working conditions and distance from family. Winnie Grandy's case, however, shows that social factors such as race and gender, as well as religion, shaped young women's identities and their experiences as ungraded teachers in Newfoundland schools.

\section{"She got a lot of accolades in the teaching profession"}

While Winnie's living and working conditions as an ungraded teacher were challenging at Battle Harbour, they did not deter her from continuing in the occupation and striving for better schools. In discussing Winnie's subsequent appointments the Grandys portrayed her as a highly motivated and successful teacher. Her daughter Margie commented that Winnie loved teaching and in a different era might have been "a career woman and her career would have been education."72 Winnie's teaching record implicitly supports this claim for it shows that in the remaining eight years of her work in Church of England schools she quickly shed her ungraded status and took advantage of the opportunity to qualify as

70 H. Harper, “Woman Teacher as Transient,” Redress 11, 2 (2002): 22.

71 D. Gruenewald, "The Best of Both Worlds: A Critical Pedagogy of Place," Educational Researcher 32, 4 (2003): 5.

72 M. Mercieca, transcript of an interview with Judith Peppard, June 2003; see also J. Campbell, transcript of an interview with Judith Peppard, June 2003. 
a second-grade teacher. The final section of this paper combines administrative details from Winnie's teaching record with information provided by the Grandys to explicate her life and work as a qualified professional teacher in Newfoundland schools.

When Winnie returned from Battle Harbour she took a position at Foxtrap at the beginning of the 1935/36 school year and was granted the third-grade teacher's certificate on 1 January 1936. Having spent a year at Foxtrap, she secured a position at Frenchman's Cove, three miles from Garnish, at the beginning of the 1936/37 school year. ${ }^{73}$ She lived with her family and rode a Hercules bicycle back and forth to her school each day, weather permitting. In the winter she stayed with a cousin who lived at Frenchman's Cove. ${ }^{74}$ In April 1937 the Church of England Board of Examiners accepted Winnie's application to attend the 1937 Summer School, which was to be held at Memorial University College in St John's from 5 July to 7 August, and which would enable her to qualify as a second-grade teacher. ${ }^{75}$

Winnie was one of 350 teachers whose attendance at the Summer School was subsidized by the Department of Education in that it paid their fares to St John's. She was enrolled in the "Professional Course," which required her to complete a compulsory topic, "Psychology and Principles of Learning and Teaching," three methodology topics, and one recreational activity. The 1937 participants chose from Primary Methods, English, Arithmetic and Mathematics, Health and Physical Education, Social Studies, Nature Study, and Household Arts, along with the recreational courses of Art, Singing, Scouting or Guiding, and Games. ${ }^{76}$ The Summer School was an intense combination of academic and social activities, beginning early in the mornings and extending into the evenings when participants were addressed by eminent men and women on a range of topics, thereby encouraging their interests in educational and world affairs. The intention, it seems, was to produce qualified professional teachers who would not only use appropriate pedagogy but also be able to contribute confidently to society. Winnie passed her final exams and was awarded her second-grade certificate at the conclusion of the Summer School.

Brief though it was, the impact of summer school training on teachers' identities should be considered carefully. Applicants competed for places at the Summer School and the Department expressed its faith

73 PANL, Anglican Transfers Service/Payroll Records Book One A-K, 1907-48, PRC \#21, Box \#5, file AE3.

74 M. Grandy, transcript of an interview with Judith Peppard, June 2003.

75 Church of England Board of Examiners Minute Book Feb 13, 1926-June 12, 1942, Meeting on April 21, 1937 in No. 100.63, Church of England Board of Examiners and Council for Higher Education, 1908-1953, Box 1, Courtesy of the Diocese of Eastern Newfoundland and Labrador Archive, St John's.

76 PANL, Advertisement for Department of Education Summer School 1937 in Andrews, Ralph, Personal Files 1920s-1970s, MG 895, Box 6. 
in them by subsidizing their attendance. Teachers who had spent their careers in very small schools assembled with many of their peers, perhaps for the first time, and were brought into contact with some of the most highly qualified men and women educators in Newfoundland, plus overseas visitors. The 1937 Summer School staff included a Superintendent of Schools from Montreal, the professorial staff at Memorial University College, four district superintendents, and "city teachers of skill and experience." ${ }^{77}$ Kathleen Weiler argues that as a result of these kinds of experiences and study young women like Winnie were encouraged to see themselves as professionals, as "educated practitioners with specialized training." ${ }^{78}$ These teachers also had opportunities to be involved in many recreational, social and cultural events at the Summer School. Recreational activities were "much stressed as giving a zest and healthy tone to our life together here, and helping us all to mingle in happy comradeship." ${ }^{\prime 79}$ There were both formal receptions and informal social events such as folk dancing in the gymnasium. Here, Fred Rowe's claim is that

Attendance at the St John's summer schools brought them into contact with prominent teachers from both Newfoundland and elsewhere, giving them opportunities to improve in appearance and deportment, and introducing them, for the first time, to cultural, social and recreational activities, which until then had been part of an unknown world. Year after year hundreds of these students departed from the summer school, having acquired a remarkable degree of culture and sophistication over a period of four or five weeks. $^{80}$

And so it might have been that Winnie Grandy began to see her life and work differently after her experiences at Summer School.

As far as work was concerned, Rose Blanche was Winnie's first appointment as a second-grade teacher. She stayed there two years, followed by a year at St David's, two years at West Mines on Bell Island, brief stints at Pt. Crewe and Garnish, and a final year at Burin. ${ }^{81}$ With the exception of Pt. Crewe all of these were at least two-room schools, with West Mines having four classes. ${ }^{82}$ Yet, despite the fact that Winnie taught for seven years as a second-grade teacher, far longer than her sisters, and

77 PANL, Department of Education, "Report of the Summer School of 1937,” 2, in Andrews, Ralph, Personal Files 1920s-1970s, MG 895, Box 6.

78 Weiler, Country Schoolwomen, 173.

79 PANL, Department of Education, "Report of the Summer School of 1937," 5, in Andrews, Ralph, Personal Files 1920s-1970s, MG 895, Box 6.

80 Rowe, The Development of Education, 134.

81 See Winnie's teaching record in PANL, Anglican Transfers Service/Payroll Records Book One A-K, 1907-48, PRC \#21, Box \#5, file AE3.

82 Annual Report of the Department of Education, Newfoundland, 1944/45, 46-48. 
was reputed to have "always talked about her teaching and education and children," no stories seem to circulate among Grandy family members about life inside Winnie's classrooms. ${ }^{83}$ Like Sue, she was said to have been assigned the lower grades and her sister recalls that in Garnish she taught "beginners up to five, reader five." ${ }^{84}$ Notwithstanding the lack of specificity about her pedagogy, Winnie is consistently positioned as a mature, confident, and successful teacher during these years. Her daughter, Margie, stated: "I think she had a lot of confidence in her skills as she grew up as a teacher, because she had ten years where she taught, which is a long time to build...a bank of experience." ${ }^{85}$ Winnie's niece stated that "she got a lot of accolades in the teaching profession" and "was friends with a lot of people in the higher echelons of education like Fred Kirby [a supervisor of Church of England schools]...she was so keenly interested in teaching that she made it her business to get involved with all those people in the hierarchy of education." ${ }^{86}$ It should be noted, however, that the Grandys attributed Winnie's confidence and success to her experience, maturity, and professional networks rather than the qualifications she gained at the 1937 Summer School. They could not have so readily constructed her as an ambitious and successful teacher, indeed a professional, if she had remained in the socially and geographically isolated place of Battle Harbour.

Winnie's life apart from teaching, that is, her experiences in her local communities during this period, aligns closely but not exactly with those of her teaching sisters. Amy, Bett, and Sue had mostly taught in small places, but clergy and police as well as teachers were likely to be living in the more substantial communities in which Winnie taught as a secondgrade teacher, and together they were seen to be "a little bit different from, you know, the average person. As I said, they were looked up to."87 Perhaps Winnie's elevated status in the profession enhanced her standing in the community. It could also be that in these homogeneous Anglican communities Winnie experienced a greater sense of belonging than she had done at Battle Harbour. For example, in her photo album covering this period of her life there is a page entitled "St David's Newfoundland," where she taught from September 1939 to July 1940. A large photo of the church and another in which she and a young woman are dressed as choristers are reminders of her affiliation with the Anglican church. There

83 J. Campbell, transcript of an interview with Judith Peppard, June 2003; see also P. Hunt, transcript of an interview with Judith Peppard, June 2003.

84 J. Kittilsen, transcript of an interview with Judith Peppard, June 2003.

85 M. Mercieca, transcript of an interview with Judith Peppard, June 2003; J. Campbell, transcript of an interview with Judith Peppard, June 2003.

86 J. Campbell, transcript of an interview with Judith Peppard, June 2003; Fred Kirby was appointed as a supervisor in Church of England schools in 1936. He held this position until 1946 when he became the principal of St Michael's Church of England College in St John's. Andrews, Integration, 345.

87 M. Grandy, transcript of an interview with Judith Peppard, June 2003. 
is also a photo of Winnie with two women and four girls, the only one in the album where she is with school-aged children. Here, she is wearing a smart, tailored two-piece suit with a white shirt, promoted in the Sears catalogue as "cleverly styled so it's becoming to all," and perhaps also showing that Winnie was someone who could be looked up to in this place. ${ }^{88}$

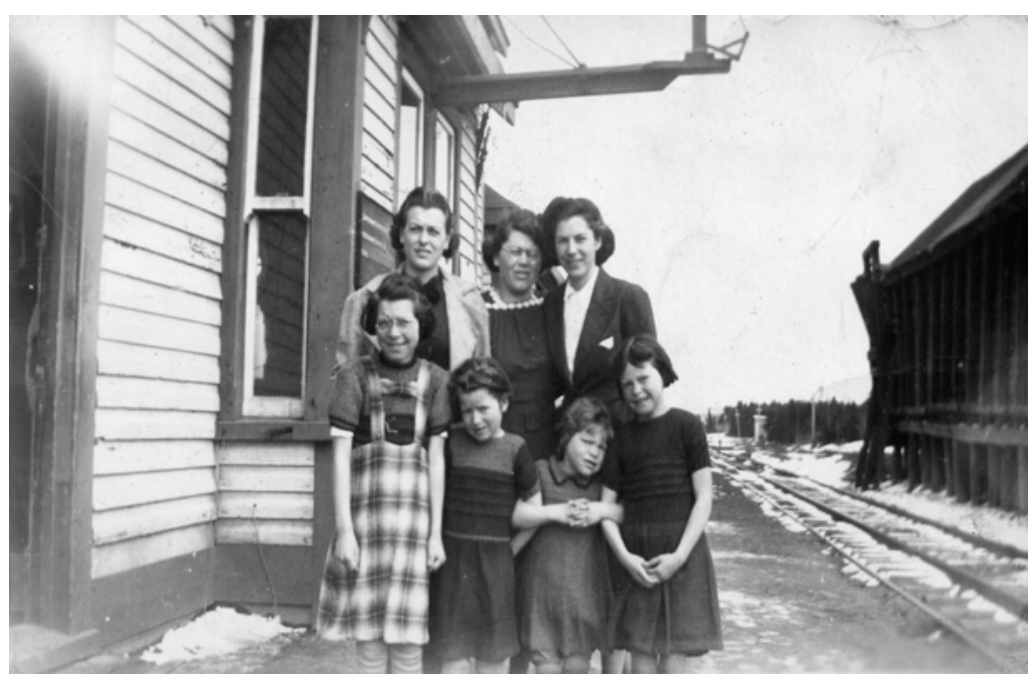

Several pages of the album display photos of Bell Island, where Winnie taught at West Mines school from September 1940 to July 1942, and the place in which she first met her future husband. According to her niece, at West Mines, Winnie "boarded with an old couple and of course she was just like their daughter." 89 The photos of daytime events on Bell Island are reminiscent of the 1937 Summer School activities - camping, hiking, and the quintessentially Newfoundland activity of fishing - and men and women are mingling in happy comradeship. There are photos of young couples enjoying social activities in the evenings too - "Party at Bell Island, 1942" and "Moonlight Party, Wabana, Bell Island, 194[?]"

88 S. Blum, Everyday Fashions of the Thirties as Pictured in Sears Catalogs (New York: Dover Publications, 1986), 114.

89 J. Walsh, transcript of an interview with Judith Peppard, June 2003. 
Thus it seems that Winnie fitted in socially at her boarding house and was able to enjoy the companionship of men and women of her own age and social standing on Bell Island, in a place much like her own in Garnish. However, when one of those relationships developed into a courtship, Winnie, like her sisters, was faced with the stark choice of marriage or paid work. After West Mines she taught for two years while her fiancé gained further teaching qualifications at Memorial University College in St John's. Winnie's teaching record indicates that she conformed to the social expectations of the time, for accumulated pension entitlements of $\$ 80.16$ were paid on account of her "marriage" when she resigned in July 1944, having spent eleven years as a teacher. Notwithstanding the many differences between the career paths and experiences of Winnie and her sisters in Newfoundland communities, they shared a common destiny, namely marriage, as did most young women teachers of this era.

THE GRANDY SISTERS were but four of countless young women who taught briefly as ungraded and third-grade teachers in Newfoundland in the interwar years. The Department of Education was dependent on their labour but ambivalent to say the least about their place in the state school system and profession. There were limited opportunities for training and certification in Newfoundland during this era, and most of these were beyond the financial resources of prospective teachers' families. Despite this situation, young women were portrayed in administrators' reports as transient and lacking the ambition to qualify as professionals, and their presumed transience was emphasized by the absence of official records for all ungraded teachers.

In focusing on the Grandy sisters, however, this paper has revealed much about the lives and valuable work undertaken by ungraded and third-grade teachers in Newfoundland. Notwithstanding their lack of credentials, these four young women were well placed in terms of their social capital to secure teaching positions. From the Grandys' perspective, the respectability and religious affiliation of Amy, Bett, and Sue also facilitated a sense of belonging and influence in the small places where they taught, albeit briefly. Nevertheless, we have resisted a romanticized description of Newfoundland teachers' work. The lives of many young ungraded teachers in outport schools were marked by geographic and social isolation, Winnie Grandy's sojourn at Battle Harbour being a case in point. While the Department of Education conceptualized loneliness and isolation as psychological problems for individual teachers, the stories that circulate within the Grandy family provide insights into the social tensions that inhered in Newfoundland society. This paper has demonstrated that people's experiences of different geographic places are structured racially, and by gender and class as well as religion, and this was certainly Winnie's experience in the heterogeneous communities of Battle Harbour and Seal Island. Her career thereafter is also illuminating, 
for both the Department and the Grandys placed her conceptually as a professional teacher. The Department accorded this status to teachers on the basis of their training and qualifications, in Winnie's case acquired at the 1937 Summer School, and kept permanent records of their employment. Stories from the Grandy family enliven the documentary record of Winnie's professional service, at the same time suggesting that her brief training might have had a profound effect on her identity. Although the Grandys never referred to the Summer School, they represented Winnie very differently as a second-grade teacher than a young ungraded teacher, and in ways that matched the Department's image of a professional. Indeed, Winnie was portrayed as an ambitious and successful teacher who enjoyed a distinguished place in the profession and in communities that were more akin to her home in Garnish than her previous situation in Battle Harbour. It could be that further research which attends closely to the lives and work of different categories of teachers, including the handful of women in higher grades than Winnie and the places in which they taught, will generate more insights into the complex nature of the Newfoundland teaching profession in the interwar years. 